\title{
Optimizing mechanical and crop physical factors for sugarcane trash recovery at farm
}

\author{
Kamran Ikram ${ }^{1,2}$,*, Yasir Niaz ${ }^{1}$, Muhammad Atif ${ }^{3}$, Muhammad Zeeshan Mansha $^{3}$, Muhammad \\ Nadeem $^{1,4}$, Muhammad Usman Ghani ${ }^{2}$, Muhammad Adnan Bodla ${ }^{1}$, Faizan Shabir ${ }^{1}$, \\ Muhammad Mohsin Waqas ${ }^{1}$ and Muhammad Nawaz ${ }^{1}$
}

${ }^{1}$ Department of Agricultural Engineering, KFUEIT, Rahim Yar Khan, Pakistan; ${ }^{2}$ Department of Farm Machinery and Power, University of Agriculture Faisalabad, Pakistan; ${ }^{3}$ Department of Plant Pathology, Bhadarpur Campus, Layyah, BZU, Multan,

Pakistan; ${ }^{4}$ Department of Engineering, Faculty of Agriculture, Dalhousie University,

39 Cox Road, Truro, Nova Scotia, B2N 5E3, Canada

*Corresponding author's e-mail: kamranikram@kfueit.edu.pk

Increasing fuel prices in international market and depletion of fossil fuel resources are reasons to find new and cheap energy resources to meet increasing energy demands throughout the world. Potential energy resources include wind, solar, geothermal, tidal and biomass. Biomass can be collected from wheat, rice and sugarcane fields. Sugarcane is most abundant cultivated crop in world providing trash (leaves and tops) and baggas as renewable energy resource for power generation which can replace $50 \%$ use of fossil fuels. Because of poor sugarcane mechanization status in Pakistan, traditional practice to get rid of this extraneous material is to burn the trash in standing crop or by manual means which is hectic due to decreasing labour availability for agricultural practices. $20-30 \%$ trash is delivered to mill along with stalk due to poor cleaning efficiency resulting deduction in farmer payment and lowering mill sugar recovery efficiency. Sugarcane stripping machine was developed for small scale farmers and different mechanical and crop physical factors were investigated to improve trash recovery and to reduce labour dependence and in field burning practice on local farms during 2018-2019 at University of Agriculture Faisalabad. The investigating crop physical factors included crop varieties ( $\left.\mathrm{V}_{1}=\mathrm{US}-658, \mathrm{~V}_{2}=\mathrm{HSF}-240, \mathrm{~V}_{3}=\mathrm{CPF}-249\right)$, moisture content in trash $\left(\mathrm{MC}_{1}=8.2, \mathrm{MC}_{2}=17.6\right)$ and mechanical factors included velocity ratio between intake rollers $\left(\mathrm{VR} \mathrm{R}_{1}=1.3\right.$, $\left.\mathrm{VR}_{2}=1.7, \mathrm{VR}_{3}=1.9\right)$, cleaning element speeds $\left(\mathrm{CE}_{1}=660 \mathrm{rpm}, \mathrm{CE}_{2}=763 \mathrm{rpm}, \mathrm{CE}_{3}=1033 \mathrm{rpm}\right)$ and intake roller combinations types $\left(\mathrm{C}_{1}, \mathrm{C}_{2}, \mathrm{C}_{3}\right)$. Three replications for each factor were recorded and data was statistically analyzed under factorial design. Results revealed that by combining $\mathrm{V}_{1}, \mathrm{MC}_{1}, \mathrm{VR}_{2}, \mathrm{CE}_{3}$ and $\mathrm{C}_{3}$ factors, trash recovery efficiency of $97 \%$ can be achieved.

Keywords: Sugarcane, energy, trash, stripping, mechanization. optimization of striper.

\section{INTRODUCTION}

Pakistan is fronting serious energy crisis since last decade. Energy shortage in form of electricity, natural gas and oil not only influenced the normal life but the industry is also in decline situation. Renewable energy resources are best suited solution to meet these energy crises including biomass, solar energy, wind energy and tidal energy. Total biomass production in country is estimated about 69 million tons. Biomass is used by direct combustion, gasification, pyrolysis, trans esterification, fermentation and an-aerobic digestion for energy generation [Mahar, 2012; Kamran, 2018].

Sugarcane provides biofuel and sugar beside fiber and fertilizer contributing key part in agricultural residues production (Chandel et al., 2012; Bastin and Sharidar, 2014).
It has global reflexion for energy generation due to balance between greenhouse gases and energy production (Macedo et al., 2008; Renouf et al., 2008; Smeets et al., 2009). During 2019-2020, the crop was sown on 1040 thousand hectares with an average of 64 ton/hectare (ESP, 2019-20). Crop residue includes trash (leaves+tops) and bagasse which comprises hemicellulose, cellulose, protein and lignin (Zhao et al., 2009; Canilha et al., 2011; Diedericks et al., 2012; Zhang et al., 2013). Trash amount vary from 6-30 ton/ha depending upon crop variety and climate conditions providing estimate of minimum 6.2 million tons trash per year in country (Trivelin et al., 1995; Vitti et al., 2011; Fortes et al., 2012, Chandel et al., 2012). Trash from one hectare generates energy equivalent to 10 ton of coal reflecting country energy potential equal to 10400 thousand ton of coal (Devi et al.,

Ikram, K., Y. Niaz, M. Atif, M.Z. Mansha, M. Nadeem, M.U. Ghani, M.A. Bodla, F. Shabir, M.M. Waqas and M. Nawaz. 2021. Optimizing mechanical and crop physical factors for sugarcane trash recovery at farm. Pak. J. Agri. Sci. 58:1383-1393.

[Received 22 Dec 2020; Accepted 26 Jul 2021; Published (online) 21 Sep 2021] 
2020). Deepchand (1986) reported that 100 GJ energy can be recovered per hectare from sugarcane trash. Net calorific value (NCV) for trash can be calculated by following formula (Deepchand, 1986)

$$
\begin{aligned}
N C V\left(B T U l b^{-1}\right) & =G C V \frac{f}{100}+7120 \frac{S}{100}+7380 \frac{i}{100} \\
& -630 \frac{100-w}{100}-1080 \frac{w}{100}
\end{aligned}
$$

Where, $\mathrm{f}=$ fiber $(\%), \mathrm{S}=\operatorname{sugar}(\%), \mathrm{i}=$ impurity $(\%)$ and $\mathrm{w}=$ water $(\%)$

Sugarcane harvesting is labor intensive and time-consuming process which takes nearly $45 \%$ of total cultivation cost (Bastin and Sharidar, 2014). The harvesting of sugarcane includes cutting of stalk and removal of trash. Trash removal takes $65 \%$ of total harvesting time (Ikram et al., 2019). As local farmers are not capable to buy expensive large-scale harvester due to socio-economic issues, conventional practice to get rid of trash is burning in field or by manual operation (Dawson and Boopathy, 2007). 75\% of total trash is burnt and $25 \%$ is left on the field as waste (Maues, 2007). Burning action not only deplete this renewable energy resource (trash) but also generates particles $(<10 \mu \mathrm{m})$ which cause bronchitis, asthma and other lung diseases (Dawson and Boopathy, 2006). Cansee (2010) found this burning depletes sugarcane sweetness, weight, sugar recovery and soil organic matter. Manual removal left 20-30\% trash with cane stalk due to unskilled labor which cause operational problems at mill. Presence of trash causes up to $10 \%$ deduction in selling price for farmer by sugarcane mill (Ashfaq et al., 2014).

Therefore, it is required to develop mechanical mean for small scale farmer for trash removal and finding best suited parameters for efficient trash recovery. The hypothesis for experiment was to develop local technology which should facilitate the farmers by mean of lowering labour dependence and recover maximum sugarcane trash.

\section{MATERIALS AND METHOD}

The experiment was carried out at farm fields of University of Agriculture Faisalabad, Pakistan during 2018-19. The fabricated trash removing machine was consisted of intake rollers, cleaning element, outlet rollers, power source and power transmission system (Table 1).

To adjust roller spacing, the maximum and minimum diameters of sugarcane stalk, 12 common sugarcane varieties were selected and diameter of 10 sugarcane stalk from top, middle and bottom for each variety was recorder. The mean values of stalk diameters are given in Table 2.

Experimental Procedure for Performance Evaluation of Sugarcane Stripping Machine: The trash amount depends upon climate conditions, crop variety, harvesting method and moisture contents (Romero, 2009). Thereby following factors were selected to find most suited interaction level for trash recovery
1. Crop veriety

2. Moisture content in trash

3. Vlocity ratio between input rollers

4. Cleaning element speed

5. Intake Roller Combinations

Table 1. Specifications of Trash Removing Machine.

\begin{tabular}{ll}
\hline Particular & Specifications \\
\hline Engine Power & $13 \mathrm{hp}$ \\
Engine RPM & 3200 \\
Engine Shaft Pulley & 2 inch diameter (B-type) \\
Main shaft RPM & 700 \\
Main shaft Pulley & 9 inch diameter (B-type) \\
Main shaft Sprocket & 17 teeth \\
Main shaft Pulleu for cleaning & 3 inch diameter (B-type) \\
element & \\
Diameter of intake/outlet rollers & $120 \mathrm{~mm}$ \\
Diameter of cleaning element & $120 \mathrm{~mm}$ \\
Intake/outlet rollers RPM & 260 \\
Intake/outlet roller Sprockets & 46 teeth \\
Cleaning element RPM & $650-1100$ \\
Pulley attached with cleaning & $1.75 \mathrm{inch}$ diameter (B type) \\
element & \\
Spring specifications & $\mathrm{L}_{\mathrm{s}}=44 \mathrm{~mm}$ \\
& $\mathrm{~L}_{\mathrm{f}}=88 \mathrm{~mm}$ \\
& $\mathrm{~N}_{\mathrm{a}}=11$ \\
& $\mathrm{~d}=4 \mathrm{~mm}$ \\
\hline
\end{tabular}

Table 2. Mean Sugarcane Stalk Diameter (cm).

\begin{tabular}{lcc}
\hline Sugarcane & \multicolumn{2}{c}{ Diameter $_{(\text {mean })}$} \\
\cline { 2 - 3 } Varitiey & D $_{\min }$ & D $_{\max }$ \\
\hline HSF-240 & 3.1 & 2.2 \\
CPF-246 & 3.4 & 2.2 \\
CPF-247 & 3.2 & 2.3 \\
CPF-248 & 3.1 & 2.2 \\
CPF-249 & 3.7 & 2.2 \\
US-127 & 2.9 & 1.9 \\
US-633 & 3.2 & 1.7 \\
US-778 & 3.3 & 1.9 \\
US272 & 3.6 & 2.6 \\
US-658 & 4.1 & 2.7 \\
US-54 & 3.4 & 2.2 \\
AUS-190 & 3.8 & 2.4 \\
\hline
\end{tabular}

Crop Variety: Locally grown varieties have intensive trash amount which make it difficult to remove this extranous material more efficiently (Ashfaq et al., 2014). The morphological study of sugarcane drscribed that leaves at top have greater anti-crushing ability while lower leaves have less anti-crushing strength (Xiangwei et al., 2006). Three sugarcane varieties $\left(\mathrm{V}_{1}=\mathrm{US}-658, \mathrm{~V}_{2}=\mathrm{HSF}-240, \mathrm{~V}_{3}=\mathrm{CPF}-\right.$ 249) were selected according to recommendations of Sugarcane Research Division of Ayub Agriculture Reseach Institute, Faisalabd, Pakistan. The stalk to trash ratio was also calculated as given in Table 3. 
Table 3. Sugarcane Trash to Stalk Ratio for Selected Varieties.

\begin{tabular}{lccc}
\hline $\begin{array}{l}\text { Sugarcane } \\
\text { Variety }\end{array}$ & $\begin{array}{c}\text { 10 Stalk } \\
\text { Weight }(\mathbf{k g})\end{array}$ & $\begin{array}{c}\text { Trash } \\
\text { Weight }(\mathbf{k g})\end{array}$ & $\begin{array}{c}\text { Trash to } \\
\text { Stalk Ratio }\end{array}$ \\
\hline US-658 & 14.74 & 5.32 & 0.36 \\
HSF-240 & 13.97 & 3.62 & 0.26 \\
CPF-249 & 10.05 & 3.74 & 0.37 \\
\hline
\end{tabular}

Moisture in Leaves: Mou et al., (2013) stated that with more trash moisture, trash removal becomes difficult. For efficient removal of stalk leaves ir is compulsory that moisture level should be low. On the other end long standing of stalk in field may cause reduction in cane weight. To investigate this effect, sugarane stalks were taken during month of December and March. The calculated moisture in March $2019\left(\mathrm{MC}_{1}\right)$ and December $2018\left(\mathrm{MC}_{2}\right)$ month was $8.2 \%$ and $17.6 \%$ respectively.

Velocity Ratio between Intake Rollers: The intake rollers provide pressing action to pass sugarcane forward which also make trash soft. Along with softening of trash by pressing action, the rubbing action was also applied by provision of velocity ratio among itake rollers using different combinations of gears. Three levels of velocity ratio $\left(\mathrm{VR}_{1}=1.3, \mathrm{VR}_{2}=1.7, \mathrm{VR}_{3}=1.9\right)$ were slected for machine efficiency calculation.

Cleaning Element Speed: Tyre ply was used as cleaning material on cleaning element due to flexible nature and easily available material. Jin et al., (2016) found flexible materials are best suited for leaf stripping process because they cause less stalk damages. Two clening elements were provided in the machine aligned with intake rollers. Three cleaning element speeds $\left(\mathrm{CE}_{1}=660 \mathrm{rpm}, \mathrm{CE}_{2}=763 \mathrm{rpm}, \mathrm{CE}_{3}=1033\right.$ $\mathrm{rpm})$ were selected to investigate the cleanig efficiency. The cleaning material was adjusted at spiral angle of $30^{\circ}$ and top feeding was adopted for efficient trash removal (Xiao et al., 2009, Bastin and Sharidar, 2014).

Intake Rollers Combinations: Intake rollers were responsible to pass the sugarcane stalk and provide facility to hold the stalk when cleaning element is removing trash. Two intake rollers were fabricated with lower roller was fixed in design and upper roller was changed with three different options. The basic purpose of these combinations was to grip the stalk effectivey and provide facility to cleaning element by softening thr grip of trash by pressing actio. The three roller designs included the following

1. Intake roller with straight bars $\left(\mathrm{C}_{1}\right)$

2. Intake rollers with spring supported continuous bars $\left(\mathrm{C}_{2}\right)$

3. Intake rollers with spring supported discontinuous bars $\left(\mathrm{C}_{3}\right)$

The third combination was selected for individual pressing of each sugarcane stalk beneath each spring.

Machine Efficiency: Machine efficiency was calculated interms of trash removal. To calculated the machine efficiency, initial weight of the cane was recorded and after passing through the machine the cane weight was again recorded. To calculate the total trash present, the leaves left on the cane stalk were removed manualy to find out the total amount of trash and hence to calculate the leaf strpping efficiency. The machine efficiency was calculated using the following formula given by Bastin and Sharidar (2014).

$$
\eta=\frac{M_{1}-M_{2}}{M_{2}-M_{3}}
$$

Where, $M_{1}$ was the mass of de-topped cane stalk, $M_{2}$ was the mass of de-trashed canestalk and $\mathrm{M}_{3}$ was mass of clean cane stalk.

Machine Capacity: The capacity of sugarcane stripping machine was projected by determining weight of sugarcane stalk de-trashed by machine and total time taken in operation. Ashfaq et al., (2014) offered equation to make machine capacity calculatons.

\section{Table 4. Experimental Setup.}

\begin{tabular}{lll}
\hline Particular & Levels & Specifications \\
\hline Moisture Content & $\mathrm{MC}_{1}$ & $8.2 \%$ \\
Crop Variety & $\mathrm{MC}_{2}$ & $17.6 \%$ \\
& $\mathrm{~V}_{1}$ & US-658 \\
& $\mathrm{V}_{2}$ & $\mathrm{HSF}-240$ \\
Velocity Ratio & $\mathrm{V}_{3}$ & CPF-249 \\
& $\mathrm{VR}_{1}$ & 1.3 \\
& $\mathrm{VR}_{2}$ & 1.7 \\
Cleaning Element Speed & $\mathrm{VR}_{3}$ & 1.9 \\
& $\mathrm{CE}_{1}$ & 660 \\
& $\mathrm{CE}_{2}$ & 763 \\
\multirow{5}{*}{ Intake Roller Combinations } & $\mathrm{CE}_{3}$ & 1033 \\
& $\mathrm{C}_{1}$ & - \\
& $\mathrm{C}_{2}$ & - \\
& $\mathrm{C}_{3}$ & - \\
\hline
\end{tabular}

Statistical Analysis: The data was recorded for described levels of chosen factors and was analyzed using factorial design using Statistics-8.1 software. The table 5 is presenting the significance of individual factor.

\section{RESULTS}

Effect of Moisture Content, Sugarcane Crop Variety, Cleaning Element Speed and Intake Roller Combinations $(M C \times V \times C E \times C)$ on Leaf Stripping Efficiency: Interactional effect of $\mathrm{MC}, \mathrm{V}, \mathrm{CE}$ and $\mathrm{C}$ is presented in figure $2 . \mathrm{MC}_{1}$ unveiled better dry leave stripping efficiency than $\mathrm{MC}_{2}$ for nearly all levels $\mathrm{V}, \mathrm{C}$ and $\mathrm{CE} . \mathrm{MC}_{2}$ unveiled better dry leave stripping efficiency for all levels of $\mathrm{CE}$ and $\mathrm{C}$ in contrast with $\mathrm{V}_{1}$. Dry leave removal for $\mathrm{V}_{1}$ was more in $\mathrm{MC}_{1}$ than $\mathrm{V}_{2}$ and $\mathrm{V}_{3}$. $\mathrm{CE}_{2}$ and $\mathrm{CE}_{3}$ had $96 \%$ and $95 \%$ dry leave efficiency respectively for $\mathrm{C}_{2}$. The contrast of $\mathrm{MC}_{1}, \mathrm{~V}_{1}, \mathrm{CE}_{2}$ and $\mathrm{C}_{2}$ had maximum (96\%) leave removing efficiency following by $\mathrm{MC}_{1}, \mathrm{~V}_{1}, \mathrm{CE}_{3}$ and $\mathrm{C}_{2}$ combination. Lowest dry leave stripping efficiency $(42 \%)$ was unveiled by $\mathrm{MC}_{2}, \mathrm{~V}_{3}, \mathrm{CE}_{2}$ and $\mathrm{C}_{2}$ 
contrast. The results are also illustrating that $\mathrm{C}_{2}$ has maximum efficiency only for $\mathrm{V}_{1}$ with $\mathrm{MC}_{1}$. All other results are illustrating $\mathrm{C}_{3}$ as most effective combination for dry leave stripping for all contrasts of $\mathrm{MC}, \mathrm{V}$ and $\mathrm{CE}$.

Effect of Moisture Content, Velocity Ratio, Cleaning Element Speed and Intake Roller Combinations $(M C \times V R \times C E \times C)$ on Leaf Stripping Efficiency: The interactional effect of $\mathrm{MC}, \mathrm{VR}, \mathrm{CE}$ and $\mathrm{C}$ is shown in the figure 3 . In this contrast $\mathrm{MC}_{1}$ gave the highest dry leave stripping efficiency as compared to $\mathrm{MC}_{2}$ with all levels of other parameters. Results are indicating that $\mathrm{VR}_{2}$ has better dry leave stripping efficiency for $\mathrm{MC}_{1}$ and $\mathrm{MC}_{2}$ as compared with $\mathrm{VR}_{1}$ and $\mathrm{VR}_{3}$. The cleaning element speed had direct relation with dry leave stripping efficiency that with increase in cleaning element speed the stripping efficiency had improved except for $\mathrm{MC}_{2}$ where in relation to $\mathrm{VR}_{3}$, the $\mathrm{CE}_{2}$ has less leaf stripping efficiency than $\mathrm{CE}_{1} . \mathrm{C}_{3}$ had unveiled better leaf stripping efficiency than $\mathrm{C}_{1}$ and $\mathrm{C}_{2}$ for all levels of $\mathrm{MC}, \mathrm{CE}$ and VR. In this contrast the maximum leaf stripping efficiency (94\%) was observed for $\mathrm{MC}_{1} \times \mathrm{VR}_{2} \times \mathrm{CE}_{3} \times \mathrm{C}_{3}$ and lowest leaf stripping efficiency $(47 \%)$ was observed for $\mathrm{MC}_{2} \times \mathrm{VR}_{3} \times \mathrm{CE}_{2} \times \mathrm{C}_{2}$.

Effect of Sugarcane Crop Variety, Velocity Ratio, Cleaning Element Speed and Intake Roller Combinations $(\boldsymbol{V} \times \boldsymbol{V R} \times \boldsymbol{C E} \times \boldsymbol{C})$ on Leaf Stripping Efficiency: The interactional effect between V, VR, CE and C is shown in the figure 4. The results are revealing that $\mathrm{V} 1$ has highest sugarcane dry leaf stripping efficiency than $V_{2}$ and $V_{3}$. On the same side $\mathrm{VR}_{2}$ had better performance than $\mathrm{VR}_{1}$ and $\mathrm{VR}_{3}$ for all levels of $\mathrm{CE}$ and $\mathrm{C}$. the highest impact of $\mathrm{VR}_{2}$ was found for $V_{1}$ and lowest was found for $V_{2}$ and $C_{1}$ with $C_{1}$. The cleaning element speed had direct impact for leaf stripping efficiency as followed other contrasts. The CE had shown the direct relation with leaf stripping efficiency that with increase in speed the stripping efficiency was increased for all combinations of VR, CE and $\mathrm{C}$. The factor $\mathrm{C}_{3}$ had also better leaf stripping efficiency for all combinations of VR, CE and $\mathrm{V}$. The figure results also indicated that highest and lowest cleaning efficiency was $97 \%$ and $49 \%$ for $\mathrm{V}_{1} \times \mathrm{VR}_{2} \times \mathrm{CE}_{2} \times \mathrm{C}_{3}$ and $\mathrm{V}_{3} \times \mathrm{VR}_{3} \times \mathrm{CE}_{2} \times \mathrm{C}_{2}$ interactional combinations respectively.

Effect of Moisture Content, Velocity Ratio, Sugarcane Crop Variety and Intake Roller Combinations $(M C \times V R \times V \times C)$ on Leaf Stripping Efficiency: The results in the figure 5 are presenting the leaf stripping efficiency for different levels of $\mathrm{MC}, \mathrm{VR}, \mathrm{V}$ and $\mathrm{C}$. The results unveiled that $\mathrm{MC}_{1}$ had better leaf stripping efficiency than $\mathrm{MC}_{2}$. $\mathrm{VR}_{2}$ was found more effective to strip dry leaves for both $\mathrm{MC}_{1}$ and $\mathrm{MC}_{2}$ but its effect was more significant with $\mathrm{MC} 1$. Crop Variety $\mathrm{V}_{1}$ had better leaf stripping efficiency than $\mathrm{V}_{2}$ and $\mathrm{V}_{3}$ for all levels of $\mathrm{MC}, \mathrm{VR}$ and $\mathrm{C}$. $\mathrm{V}_{2}$ had shown least efficiency and had lowest value with $\mathrm{VR}_{1}$ and $\mathrm{MC}_{2}$. The $\mathrm{C}_{3}$ had better cleaning efficiency than $C_{1}$ and $C_{2}$ for all levels of other parameters. Only $C_{2}$ had better stripping efficiency for $V_{1}, V_{2}$ and $M_{1}$.
$\mathrm{C}_{3}$ had better leaf stripping efficiency than $\mathrm{C}_{1}$ and $\mathrm{C}_{2}$. The maximum efficiency for this was observed for $\mathrm{MC}_{2}, \mathrm{VR}_{2}$ and $\mathrm{V}_{1}$. On average better results were observed for $\mathrm{MC}_{1} \cdot \mathrm{C}_{2}$ on the other had showed better leaf stripping efficiency $(97 \%)$ only for $\mathrm{MC}_{1}, \mathrm{~V}_{1}$ and $\mathrm{VR}_{2}$ contrast. Lowest cleaning efficiency was $42 \%$ for $\mathrm{MC}_{2} \times \mathrm{V}_{3} \times \mathrm{VR}_{1} \times \mathrm{C}_{1}$ interactional combinations.

Effect of Moisture Content, Velocity Ratio, Sugarcane Crop Variety and Cleaning Element Speed $(M C \times V R \times V \times C E)$ on Leaf Stripping Efficiency: The effect of interaction between $\mathrm{MC}, \mathrm{VR}, \mathrm{V}$ and $\mathrm{CE}$ is shown in the figure 6. The results are indicating that $\mathrm{MC} 1$ had more dry leaf stripping efficiency than MC2. For MC2 highest leaf stripping efficiency was for V1 only with all levels of VR and C. VR2 had unveiled better dry leaves stripping efficiency for MC1 and MC2 in contrast with all levels of V. V1 showed the maximum leaf stripping efficiency for all levels of MC, VR and C. The peak dry leaf stripping efficiency (97\%) was noted for $\mathrm{MC}_{1} \times \mathrm{V}_{1} \times \mathrm{VR}_{2} \times \mathrm{CE}_{2}$ and lowest stripping efficiency (45\%) was recorded for $\mathrm{MC}_{2} \times \mathrm{V}_{3} \times \mathrm{VR}_{1} \times \mathrm{CE}_{1}$ interactional combination.

Table 5. Effect of Individual Factor on Trash Removal Efficiency (E) \%

\begin{tabular}{|c|c|c|c|}
\hline \multicolumn{2}{|c|}{ Factor/Levels } & $(\%) \mathbf{E}_{\text {mean }}$ & LSD \\
\hline $\mathrm{CE}$ & $\mathrm{CE}(\mathrm{p} \leq 0.05)$ & & \\
\hline 3 & & $77.063 \mathrm{~A}$ & 2.19 \\
\hline 2 & & $73.467 \mathrm{~B}$ & \\
\hline 1 & & $73.386 \mathrm{~B}$ & \\
\hline $\mathrm{MC}$ & $\mathrm{MC}(\mathrm{p} \leq 0.05)$ & & \\
\hline 1 & & $82.840 \mathrm{~A}$ & 1.79 \\
\hline 2 & & $66.438 \mathrm{~B}$ & \\
\hline $\mathrm{C}$ & $\mathrm{C}(\mathrm{p} \leq 0.05)$ & & \\
\hline 3 & & $82.438 \mathrm{~A}$ & 2.20 \\
\hline 2 & & $71.803 \mathrm{~B}$ & \\
\hline 1 & & $69.675 \mathrm{~B}$ & \\
\hline $\mathrm{V}$ & $V(p \leq 0.05)$ & & \\
\hline 1 & & $87.721 \mathrm{~A}$ & 2.19 \\
\hline 2 & & $68.098 \mathrm{~B}$ & \\
\hline 3 & & $68.098 \mathrm{~B}$ & \\
\hline VR & VR $(p \leq 0.05)$ & & \\
\hline 2 & & $80.272 \mathrm{~A}$ & 2.20 \\
\hline 3 & & $74.588 \mathrm{~B}$ & \\
\hline 1 & & $69.057 \mathrm{~B}$ & \\
\hline
\end{tabular}

Means within a column followed by same letters are not significant at $\mathrm{p} \leq 0.05$.

Cost Analysis of Mechanical and Manual Detrashing particulars: Ashfaq et al., (2014) had developed a tractor operated sugarcane detrasher with $79 \%$ leaf stripping efficiency. The newly developed sugarcane stripper had $97 \%$ leaf stripping efficiency and has an 8hp engine instead 50hp tractor which saves the farmer cost. The cost analysis of tractor operator leaf stripper, engine operated leaf stripper and 
Sugarcane trash recovery

Table 6. Cost analysis of tractor operated and engine operated trash removal machine

\begin{tabular}{|c|c|c|c|}
\hline \multirow[t]{2}{*}{ Specifics } & \multicolumn{2}{|c|}{$\begin{array}{c}\text { Tractor Operated Sugarcane Leaf Stripper } \\
\text { (Ashfaq et al., 2014) }\end{array}$} & \multirow[t]{2}{*}{$\begin{array}{l}\text { Engine Operated Sugarcane Leaf } \\
\text { Stripper (Ikram et al., 2019) }\end{array}$} \\
\hline & Tractor (MF-240) & Sugarcane Stripper & \\
\hline Purchase Price, $\mathrm{P}$ & 897750 & 35000 & 60,000 \\
\hline Salvage Value (S), $10 \%$ of $\mathrm{P}$ & 89775 & 3500 & 6000 \\
\hline Life of Machine (Year) L & 10 & 10 & 10 \\
\hline Working Hours (Annual) & 1200 & 500 & 600 \\
\hline \multicolumn{4}{|l|}{ Fixed Cost } \\
\hline Depreciation (D) Rs. $/ \mathrm{hr} ; \mathrm{D}=(\mathrm{P}-\mathrm{S}) / \mathrm{L}$ & 67.33 & 6.3 & 9 \\
\hline Interest $(\mathrm{I}) / \mathrm{hr} ; \mathrm{I}=[(\mathrm{P}+\mathrm{S}) / 2] *_{\mathrm{i}}$ & 49.37 & 4.62 & 6.6 \\
\hline \multirow{2}{*}{\multicolumn{4}{|c|}{ Variable Cost }} \\
\hline & & & \\
\hline Maintenance and Repair (15\% P) & 112.21 & 10.5 & 1.25 \\
\hline Fuel Cost $/ \mathrm{hr}(6 \mathrm{~L} / \mathrm{hr})$ & 600 & - & 370 \\
\hline Lubrication Cost ( $15 \%$ of Fuel Cost) & 90 & - & 55.5 \\
\hline Driver Charges/hr & 87.5 & - & - \\
\hline Helper Charger/hr & - & $62.5 \times 2=125$ & $62.5 \times 3=187.5$ \\
\hline \multirow[t]{2}{*}{ Total Cost (Rs./hr) } & 1021.37 & 146.42 & \\
\hline & \multicolumn{2}{|c|}{$1021.37+146.42=1167.79 \mathrm{Rs} / \mathrm{hr}$} & $631.85 \mathrm{Rs} / \mathrm{hr}$ \\
\hline \multicolumn{4}{|l|}{ Cost Comparison } \\
\hline Working hrs/day & 16 & - & 16 \\
\hline Machine Capacity (ton/day) & 57 & - & 57 \\
\hline Operation Cost/ha & 16342 & - & 10109 \\
\hline \multicolumn{4}{|l|}{ Conventional Leaf Stripping } \\
\hline Capacity of Stripping Dry & 1 ton & & \\
\hline \multicolumn{4}{|l|}{ Leaves/day/labor } \\
\hline Leaf Stripping Cost Rs. /ton & 350 & & \\
\hline Production (ton/ha) & 55 ton & & \\
\hline Time Required (Days/ha) & 55 & & \\
\hline Total Cost Pay to Labor & 19250 & & \\
\hline \multicolumn{4}{|l|}{ Cost Benefit over Manual Stripping } \\
\hline Rs. /ha & 19250 & $342=2908$ & $19250-10109=9141$ \\
\hline
\end{tabular}

*1 US Dollar = 166 Rupees

cost paid to manual labor is done in the Table 6 .

The cost analysis shows that the mechanical detrashing is cost effective as tractor operated machine saved 2908 rupees and engine operated leaf stripper saved 9141 rupees/ha as compared with manual leaf stripping.

\section{DISCUSSION}

Sugarcane in important cash crop in Pakistan. The sugarcane juice is used for synthesis of sugar and drug (Singh et al., 2015) while its baggas and dry leaves are used by sugar mills for power generation (To et al., 2018). Before harvesting the dry leaves of sugarcane stalks are removed mechanically, manually or by burning method (Dawson and Boopathy, 2007). Mechanical harvesting includes use of large-scale harvesters which are not common among local farmers due to social and economic situations (Ikram et al., 2019). Therefor farmers are forced to manual harvesting or using burning technique. They are facing up to $10 \%$ deduction in selling price of sugarcane crop by sugar mills due to presence of impurities after manual harvesting because sugarcane trash then contaminates the sugar juice and lower the sugar quality in mill. (Ashfaq et al., 2014).

Currently, Pakistan is facing serious energy deficit. 57.9 million ton of oil equivalent was energy requirement of country in 2006 and is increasing at rate of $11-13 \%$ per year. In 2020 local energy requirement is 179 million ton of oil equivalent which will be three times more in 2050 (Din et al., 2019). To mitigate these needs, attentions to renewable energy resources should be paid. Pakistan is enriched with wind, solar, biomass and biogas energy resources (Kamran, 2018). Sugarcane trash is important source of biomass material. Conventionally these leaves are burnt in the field which waste this energy source. Sugarcane stalk consists of $70 \%$ mill able stalk, $8 \%$ tops, $15 \%$ green and $7 \%$ dry leaves (Rozeff, 1994). The trash after drying can also be used for power generation (Devi et al., 2020). 
To avoid deductions in farmer selling price and provision of dry leaves for power generation, a small-scale sugarcane leaf stripping machine was fabricated and interactional effects between different mechanical and sugarcane physical parameters were investigated in this study for maximum recovery of sugarcane trash. The selected parameters included two levels of moisture content, three sugarcane crop varieties, three levels of velocity ratio between intake rollers, three type of intake roller combinations and three levels of cleaning roller speed namely $\mathrm{MC}_{1}, \mathrm{MC}_{2}, \mathrm{~V}_{1}, \mathrm{~V}_{2}, \mathrm{~V}_{3}, \mathrm{VR}_{1}, \mathrm{VR}_{2}, \mathrm{VR}_{3}$, $\mathrm{C}_{1}, \mathrm{C}_{2}$ and $\mathrm{C}_{3}$ respectively. the results indicated that $\mathrm{MC}_{1}, \mathrm{~V}_{1}$, $\mathrm{VR}_{2}, \mathrm{C}_{3}$ and $\mathrm{CE}_{3}$ gave the maximum leaf stripping efficiency up to $(97 \%)$.

The results indicated that lower moisture contents provide ease to leaf stripping process. This was due to fact that as the leaves got dried the strong grip of leaves on sugarcane stalk become loose and this fact provides ease for cleaning element material to remove the dry leaves more easily. Sugarcane crop varieties are also important in this regard. Conventional crop varieties in Pakistan are enrich in leaves and it became difficult for machine and labor to remove these leaves because of their abundant amount. The crop variety $\mathrm{V}_{1}$ had leaves which were not tightly gripped with sugarcane stalk as were gripped for $V_{2}$ and $V_{3}$. This fact made ease for sugarcane stripping machine to remove leaves more effectively. The same results were reported by Mou et al., (2013) that moisture content level has direct relation with trash stripping. The cleaning element roller speed had shown direct relation to leaf stripping efficiency. As the roller speed increased, number of impacts with cane stalk increased which ultimately improved the cleaning efficiency. But this point is to be considered that cleaning element increased speed beyond limit may damage the germination eyes on stalk or stalk itself. The roller speed in this experiment was adjusted that there was maximum 5 strikes on the stalk between two nodes. Same results were reported by Bastin and Sharidar (2014).

The concept of velocity ratio was also used in this experiment. The velocity ratio between two rotating rollers produced a rubbing effect on sugarcane stalk. This rubbing effect was cause of losing the grip of leaves on sugarcane stalk and hence removed the dry leaves more efficiently. Observations during experiments indicated that the $\mathrm{VR}_{3}$ was not good for sugarcane stalks with more diameters. As the speed and torque are in inverse relation so as the speed of roller increased the necessary torque for push of sugarcane stalk was not provided by the roller and the roller stop there. The experimental observations concluded that velocity ratio should not be too high. The intake roller combinations played a vital role in leaf stripping process. The $\mathrm{C}_{3}$ roller had small segments with spring which helped the rolled to press the sugarcane stalk individually and hence improved the sugarcane leaf stripping efficiency. The experimental observations concluded that roller having straight bars were not fully effective to press and pass all sugarcane feed stalks because of difference in stalk diameters. A large diameter stalk caused the no-press action for other stalks.

The cost analysis for tractor operated, manual leaf stripping operation and newly developed engine operated machine revealed that mechanical harvesting is less time and labor consuming with more efficiency and less cost over manual leaf stripping process.

Conclusion: Sugarcane trash is highly valuable energy resource producing in abundant in Pakistan. Lack of knowledge about its benefits, non-availability of mechanical means for harvesting and socio-economic conditions of farmers force them to use conventional manual or field burning method to get rid of this extraneous material. Use of mechanical means in form of small machinery can facilitate the farmers in terms of labour dependence and cost. Trash recovery depends upon physical and mechanical parameters of crop and trash removing machine including leaf moisture, crop variety, intake roller type, cleaning element speed and velocity ratio between rollers. Maximum trash recovery will facilitate in terms of energy production and less deduction in selling price for farmers. Government needs to pay serious attention for 1 . Aware the farmers about benefits of trash 2 . promote mechanical harvesting of sugarcane by means of providing large scale harvesters on rent or promoting small scale machinery 3 . instalment of power plants operating on this trash to limit the dependence on fossil fuels and avoid depletion of this renewable energy resource.

Acknowledgment: This work was funded by Punjab Agriculture Research Board (PARB) through University of Agriculture Faisalabad, Pakistan. (PARB Project \# 445). Moreover, special thanks to Prof. Dr. Manzoor Ahmad, Dr. Anjum Munir, Dr. Abdul Ghafoor and all staff members of Farm Machinery Lab, UAF for their support during this research.

\section{REFERENCES}

Ashfaq, S., A. Ghafoor, M. Ahmad and Q. Yaqub. 2014. Performance evaluation of sugarcane stripper for trash recovery. Int. J. Ren. Energy Res. 4:992-997.

Bastian, J. and B. Sharidar. 2014. Investigations on sugarcane detrashing mechanism. Int. J. Engg. Res. 3:453-457.

Bastian, J and B. Shridara. 2014. Investigation on Mechanical Properties of Sugarcane Stalks for the Development of a Whole Cane Combine Harvester. Indian J. App. Res. 4:13.

Canilha, L., V.T.O. Santos, G.J.M. Rocha, J.B.A.E. Silva, M. Giulietti and S.S. Silva. 2011. A study on the pretreatment of a sugarcane bagasse sample with dilute sulfuric acid. J. Ind. Micro Biotech. 38:1467-1475. 
Cansee, S. 2010. A study on sugarcane leaf removal machinery during harvest. American J. Engg. App. Sci. 3:186-188.

Chandel, A. K., S.S.D. Silva, W. Carvalho, and O.V. Singh. 2012. Sugarcane bagasse and leaves: foreseeable biomass of biofuel and bio-products. J. Chem. Tech \& Biotech. 87:11-20.

Dawson, L. and R. Boopathy. 2007. Use of post-harvest sugarcane residue for ethanol production. Biores. Tech. 98:1695-1699.

Deepchand. 1986. Sugar cane tops and leaves as a raw material for pulp and paper. Biological Wastes. 19:69-73.

Devi, G.K. and V.S. Chozhavendhan. 2020. Effective utilization of sugarcane trash for energy production. Refining Biomass Residues for Sustainable Energy and Bioproducts. Ref. Biomass Res. Sus. Energy Bioproducts. 15:259-273.

Diedericks, D., E.V. Rensburg, M.D. Garcia-Aparicio and J.F. Gorgens. 2012. Enhancing the enzymatic digestibility of sugarcane bagasse through the application of an ionic liquid in combination with an acid catalyst. Biotech. Prog. 28:76-84.

Din, W., K. Ayesha, A.H. Zeba, B. Khan, S. Islama, M. Ishfaqa, I. Khana, M. Adild and H.J. Kima. 2019. Current and future prospects of small hydro power in Pakistan: A survey. Energy Strat. Rev. 24:166-177.

Economical Survey of Pakistan, 2019-2020. Agriculture. Ministry of Finance, Govt. of Pakistan. Available at http://www.finance.gov.pk/survey_1920.html.

Fortes, C., P.C.O. Trivelin, A.C. Vitti, D.A. Ferreira, H.C.J. Franco, and R. Otto. 2011. Recovery of nitrogen (15N) by sugarcane from previous crop residues and urea fertilisation under a minimum tillage system. Sugar Tech. 13:42-46.

Ikram, K., M. Ahmad, A. Ghafoor, and A. Tanveer. 2019. Design, fabrication and performance evaluation of indigenous sugarcane leaf stripping machine. Pak. J. Agri. Sci. 56:451-457.

Javed, M.S., R. Raza, I. Hassan, R. Saeed, N. Shaheen, J. Iqbal, and S.F. Shaukat. 2016. The energy crisis in Pakistan: A possible solution via biomass-based waste. J. Ren. Sus. Energy. 8:043102.

Jin, X., X. Du, D. Wang, W. Liu and J. Ji. 2016. Flexible plate teeth type sugarcane leaf stripping device. Int. J. Hybrid Info. Tech. 09:57-66.

Kamran, M. 2018. Current status and future success of renewable energy in Pakistan. Renew. Sus. Energy Rev. 82:609-617.

Macedo, I., J. E. A. Seabra, and J.E.A.R Silva. 2008. Greenhouse gases emissions in the production and use of ethanol from sugarcane in Brazil: the 2005/2006 averages and a prediction for 2020. Biomass and Bioenergy. 32:582-595.

Mahar R.B., A.R. Sathio, and M.A. Uqaili. 2012. Biomethanization potential of waste agricultural biomass in Pakistan: A case study. Int. J. Biomass Ren. 1:32-37.
Maues, J. A. 2007. Optimization of power generation from bagasse and sugarcane waste in a Brazilian sugar and alcohol mill. Proc ISES Solar World Con, Solar Energy Human Sett. 5:2444-2448.

Mou, X., Q. Liu, Y. Ou, M. Wang and J. Song. 2013. Mechanical properties of leaf sheath of sugarcane. American Soc. Agri. Bio. Eng. 56:801-812.

Renouf, M. A., M.K. Wegener and L.K. Nielsen. 2008. An environmental life cycle assessment comparing Australian sugarcane with US corn and UK sugar beet as producers of sugars for fermentation. Biomass Bioenergy. 32:1144-1155.

Rozeff, N. 1994. Sugar cane biomass and burning: An empirical scenario for the lower Rio Grande Valley of Texas. Sugarcane. Pp. 2-5.

Singh, A., U.R. Lall, H.M. Mukhtar, P.S. Singh, G. Shah and R.K. Dhawan. 2015. Phytochemical profile of sugarcane and its potential health aspects. Pharmacognosy Reviews. 9:45-54.

Smeets, E. M. W., L.F. Bouwmanw, E. Stehfest, D.P.V. Vuuren and A. Posthuma. 2009. Contribution of $\mathrm{N}_{2} \mathrm{O}$ to the greenhouse gas balance of first-generation biofuels. G. Change Bio. 15:1-23.

To, L.S., V. Seebaluckc and M. Leachd. 2018. Future energy transitions for bagasse cogeneration: Lessons from multilevel and policy innovations in Mauritius. Energy Res. Social Sci. 35: 68-77.

Trivelin, P. C. O., R.L. Victoria and J.C.S. Rodrigues. 1995. Utilization by late harvest sugar cane ratoon of nitrogen from $15 n$-aqua ammonia and $15 n$-urea applied to the soil as vinasse n-complement. Pesquisa Agro. Brasil. 30:1375-1385.

Vitti, A. C., H.C.J. Franco, P.C.O. Trivelin, D.A. Ferreira, R. Otto, C. Fortes and C.E. Faroni. 2011. Nitrogen derived from fertilization and straw for plant cane nutrition. Pesquisa Agro. Brasil. 46:287-293.

Xiangwei, M., L. Qingting, O. Yinggang and Z. Zhiqiang. 2011. Analysis on Leaf Stripping Effect of Sugarcane Feeding Way for Centrifugal Leaf Stripping Machine. IEEE. 19-23.

Xiao, L., L. Shi, L.D. Mei, J.D. Wei, L.S. Ping and Q.Z. Wen. 2009. Virtual simulation analysis and experimental study on a new peel scratch relieving design of sugarcane leaf cleaning device. International conference on measuring technology and mechatronics automation, Zhangjiajie, Hunan. pp. 2:428-431.

Zhang, Z., H.H. Wong, P.L. Albertson, W.O.S. Doherty and I.M. O'Hara. 2013. Laboratory and pilot scale pretreatment of sugarcane bagasse by acidified aqueous glycerol solutions. Bioresource Tech. 138:14-21.

Zhao, X. B., F. Peng, K. Cheng and D.H. Liu. 2009. Enhancement of the enzymatic digestibility of sugarcane bagasse by alkali-peracetic acid pre-treatment. Enzyme Micro Tech. 44:17-23. 